\title{
ASSOCIATION OF WATER AND SMALL MONOCARBOXYLIC ACIDS: MATRIX ISOLATION FTIR SPECTROMETRY STUDY
}

\author{
J. Čeponkus, D. Leščiūtè, D. Čepulinskaitè, M. Pučetaitè, and V. Šablinskas \\ Faculty of Physics, Vilnius University, Sauletekio 9, LT-10222 Vilnius, Lithuania \\ E-mail: valdas.sablinskas@ff.vu.lt
}

Received 8 December 2008; accepted 19 March 2009

\begin{abstract}
Infrared spectra of matrix isolated formic, acetic, propionic, and butyric acids mixed with water were obtained. Combining experimental data and theoretical calculations we were able to assign spectral bands arising due to formation of 1:1 complex between water and title acids. The structure of such complexes was elucidated from theoretical and spectral data for the first time. Alternating decrease of binding energy of the complexes was observed with the increase of the length of radical chain of organic acids. Alternating behaviour of hydrogen bond energy might be attributed to the weak van der Waals interaction between oxygen atom from carbonyl group and nearest hydrogen atoms from aliphatic chain of the acid.
\end{abstract}

Keywords: water, carboxylic acids, FTIR, matrix isolation, hydrogen bond complexes

PACS: 33.20.Ea, 33.15.Fm, 31.15.Ar

\section{Introduction}

Hydrogen bonding plays very important role in many aspects of physics, chemistry, and biology. This is especially true in the modern research in such fields as surface physics, biochemistry, and biophysics. Formation of hydrogen bonded complexes alters properties of the matter and might significantly influence processes occurring in chemical and biological systems. Studies of water complexes with both organic and inorganic compounds are of particular interest. Water is the most abundant chemical compound on Earth and is considered to be the essence of life [1]. In the studies of biological compounds or surfaces it is impossible to have water free samples, therefore it is very important to have knowledge of how water interacts with other substances. In most cases it is very complicated to study hydrogen bond associates in large structures and the model studies should be employed. Small monocarboxylic acids capable of forming two strong hydrogen bonds are good candidates for such studies of complexes between water and organic substances [2].

Formic acid-water and acetic acid-water complexes were studied both theoretically and experimentally [3-6]. Recently Sander and coworkers reported the observation of 1:1 and 1:2 complexes between formic acid and water from matrix isolation infrared spectroscopy measurements [7]. Similar type of associates is predicted from the theoretical calculations for higher carboxylic acids (such as acetic acid etc.). Unfortunately, to the authors' knowledge, there is no reliable matrix isolation experimental data on the structure and dynamics of such complexes.

\section{Experimental set-up}

Liquid phase samples of carboxylic acids (formic $98-100 \%$, acetic $>99.9 \%$, propionic $>99.5 \%$, butyric $>99.7 \%$ from Merck) were degassed repeating freezepump-thaw cycle in standard vacuum line and used without further purification. Water was doubly distilled and degassed. Argon from Elme Messer >99.995 was used as received.

Matrix isolated samples were prepared mixing carboxylic acid and water vapour with argon in the vacuum line. Ratios between acid, water, and matrix were determined using standard manometric technique. The acid/water ratios were varied from 1:0 (1:0 referring to the experiment without water impurities) to $1: 10$, and mixture/matrix ratio was used from 1:5000 to 1:500. Gas phase mixtures were deposited on cold (10 K) CsI window, in the close cycle helium cryostat (Leybold Heraeus RW2). Gas flow into cryostat was controlled with the needle valve. In each experiment $c a 2 \mathrm{~mol}$ of matrix mixture were deposited in one hour. 
Infrared absorption spectra were recorded on FTIR spectrometer Vertex 70 from Bruker. Spectra were obtained using $0.5 \mathrm{~cm}^{-1}$ spectral resolution, $\mathrm{KBr}$ beamsplitter, "glowbar" light source, and liquid nitrogen cooled MCT detector.

Far infrared part of the spectra was measured in Swedish National Laboratory MAX-lab. Experimental set-up for matrix sample preparation is in detail described elsewhere [8]. Briefly: water, acid, and matrix gas were introduced into the liquid helium cooled cryostat using separate inlets, the mixture ratios were set by adjusting the needle valves on each inlet. Infrared spectra in $150-700 \mathrm{~cm}^{-1}$ region were acquired using Bruker HR 120 spectrometer, 6 micron multilayer Mylar beamsplitter, glowbar (or synchrotron in some experiments) light source, and liquid He cooled Si bolometer.

\section{Calculations}

Strength of the hydrogen bond in acid dimers and acid water complexes as well as structural parameters of monomers and associates were calculated using $a b$ intio method at Hartree-Fock (HF) 6-311++G(3df,3pd) theory level [9]. This method gives accurate geometry and bonding energy, but fails when vibrational frequencies are calculated [10]. Vibrational frequencies were calculated using density functional theory (DFT) at B3LYP 6-311++G(3df,3pd) level [9]. This calculation does not take anharmonicity of the potential function into account, therefore the resulting vibrational frequencies are somewhat overestimated. It is known from the detailed studies of B3LYP functional $[10,11]$ that this method overestimates vibrational frequencies by $1-$ $3 \%$, therefore scaling the calculated spectra with the factor $k=0.98$ gives good correspondence with the experimental values.

\section{Results and discussions}

\subsection{Formic acid and water complexes}

Formic acid selfassociates are studied by very large number of scientists using various experimental and theoretical methods $[2,12]$. Formic acid monomer and dimer have been studied by means of matrix isolation infrared spectroscopy as well [13]. It is agreed that in gas phase and isolated in the noble gas matrices formic acid exists as a mixture of monomers and cyclic dimers. Recently the existence of open structure formic acid dimer isolated in argon matrices was confirmed by
Sander [7] and experimental works in Vilnius University by Sablinskas et al. [4].

Theoretical studies predict a cyclic geometry of formic acid-water complex to be the most stable [14]. First attempt to characterize this complex experimentally is performed by Engdahl [15]. In his work author reported an observation of MIR and FIR spectral bands attributed to the cyclic complex of formic acid and water. The existence of such complexes in the gas phase was later reported from microwave data by Priem et al. [6].

MIR spectra, in the so-called fingerprint region, of water and formic acid mixtures are presented in Fig. 1. At very low concentrations of water and formic acid in the matrix, only spectral bands attributed to the monomers of those two species are observed. When the concentration is increased formation of complexes can occur. Depending on the ratio between water, acid, and matrix, several types of complexes can be formed: water selfassociates, formic acid dimers, and heterocomplexes between water and formic acid. The biggest changes in the MIR spectrum related to the change of the concentrations of water and acid are observed in the spectral region of $1700-1800 \mathrm{~cm}^{-1}$. In this region spectral bands corresponding to $\mathrm{C}=\mathrm{O}$ stretch vibration of carboxylic acids are observed. Based on the theoretical calculations, this vibration is also the most sensitive to the formation of the hydrogen bond complexes. Therefore this spectral region was chosen for the detailed analysis in order to identify possible waterformic acid complexes and to determine their geometrical structure.

Spectral bands in the $1700-1800 \mathrm{~cm}^{-1}$ region are assigned according to theoretical calculations performed at B3LYP level using 6-311++G(3df,3pd) basis set [9]. Calculated binding energies and $\mathrm{C}=\mathrm{O}$ stretch vibration wavenumbers of possible complexes are presented in Table 1.

The region of IR spectra corresponding to $\mathrm{C}=\mathrm{O}$ vibrations of water and formic acid mixture, isolated in argon matrix, is presented in Fig. 2. The ratio water:acid:argon $=1: 2: 1000$ was used in this experiment. The highest wavenumber band $\left(1767.2 \mathrm{~cm}^{-1}\right)$ can be straightforwardly assigned to the $\mathrm{C}=\mathrm{O}$ vibrations of formic acid monomer on the basis of theoretical calculations. This assignment agrees perfectly with the literature data $[6,7]$. The band attributed to the cyclic associate of formic acid dimer is found at $1728.1 \mathrm{~cm}^{-1}$. This assignment agrees well with the calculated data. The two remaining spectral bands between bands of monomer and cyclic dimer are due to the open formic 


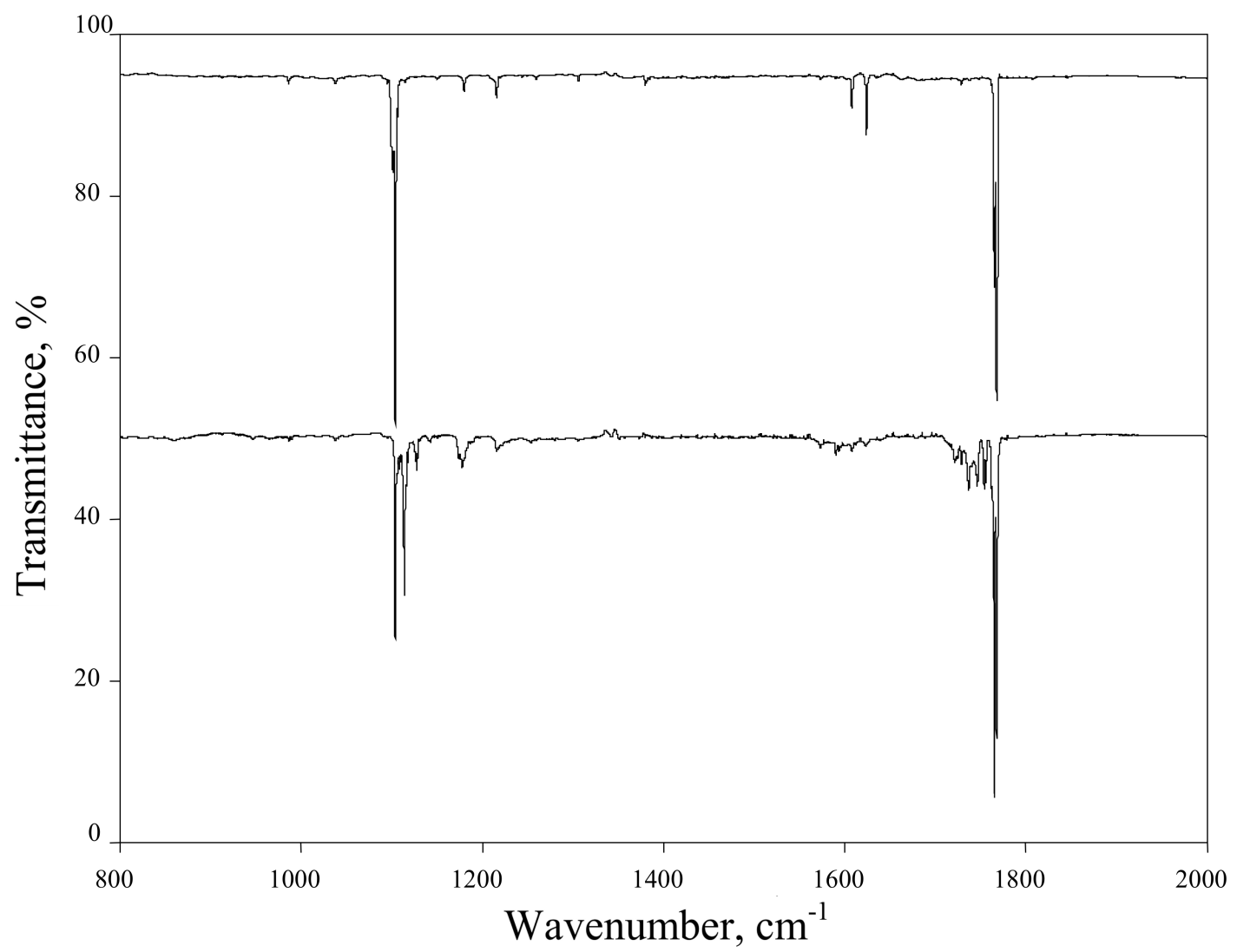

Fig. 1. "Fingerprint" region of IR spectra of formic acid and water mixtures isolated in argon matrix. Upper spectrum for formic acid:water: $\operatorname{argon}=2: 1: 5000$, lower spectrum for formic acid:water:argon $=1: 1: 2000$.

Table 1. Calculated energies and $\nu(\mathrm{C}=\mathrm{O})$ frequencies of formic acid monomers, dimers, and formic acid-water complexes.

\begin{tabular}{lccc}
\hline Structure & $\Delta H, \mathrm{~kJ} / \mathrm{mol}$ & $\nu_{\mathrm{C}=\mathrm{O}}, \mathrm{cm}^{-1}$ & Absorbance intensity, a. u. \\
\hline Monomer trans & - & 1770.3 & 496.0 \\
\cline { 2 - 4 } Dimer (cyclic) & -53.7 & 1659.6 & 0.0 \\
& & 1730.6 & 1066.2 \\
\cline { 2 - 4 } Open dimer & -33.3 & 1709.8 & 137.1 \\
& & 1749.9 & 886.7 \\
Formic acid-water 1:1 complex & -38.7 & 1738.3 & 473.1 \\
\cline { 2 - 4 } Formic acid-water 1:2 complex & -69.2 & 1712.8 & 415.5 \\
\hline
\end{tabular}

acid dimer and water-formic acid complex. Binding energy of water-acid complex is higher than that of open formic acid dimer. Therefore spectral band associated with water-acid complex should be red shifted more than the band associated with open dimer of acid. The same spectral shift pattern observed in the calculated wavenumber values of $\mathrm{C}=\mathrm{O}$ vibration in different structures. Based on those observations the spectral band at $1736.5 \mathrm{~cm}^{-1}$ is attributed to formic acid-water complex. This assignment is also confirmed from matrix annealing experiments and experiments with different water acid mixture ratios. When experiments with pure formic acid are performed, spectral band at
$1736.5 \mathrm{~cm}^{-1}$ disappears, and on the contrary, in experiments with predominant water and only small amounts of acid this band increases with respect to the cyclic and open dimer band.

In order to determine the structure of water-formic acid complex a number of possible geometries of such complex was calculated. The calculations revealed that the most stable (lowest energy) structure (Fig. 3) is cyclic. The formation of cyclic structure results in nonlinear and weaker hydrogen bonds, but formation of two weaker bonds in the cyclic structure results in a higher binding energy of all systems than in the structure with one linear hydrogen bond. In this cyclic structure both 


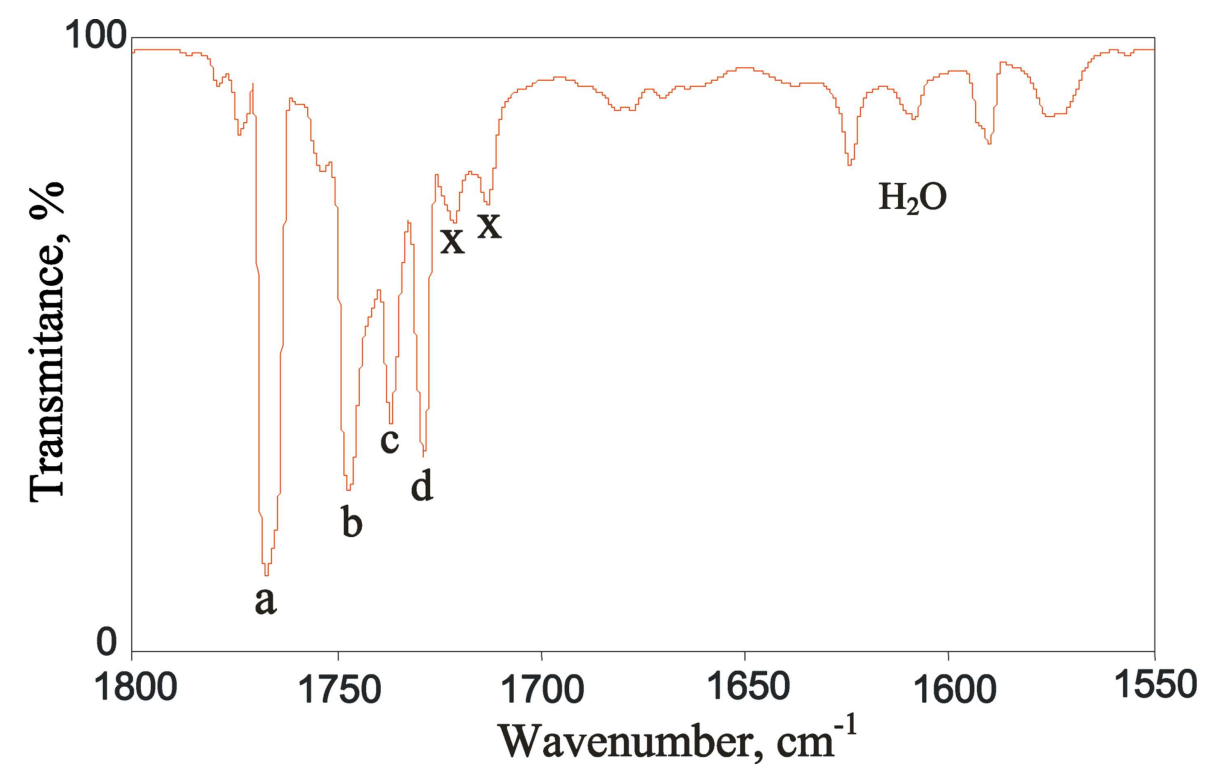

Fig. 2. Region of IR absorption spectra, corresponding to $\mathrm{C}=\mathrm{O}$ vibrations, of formic acid and water isolated in argon matrix (1:2:1000): (a) monomer, (b) open dimer, (c) water-acid complex, (d) cyclic dimer.

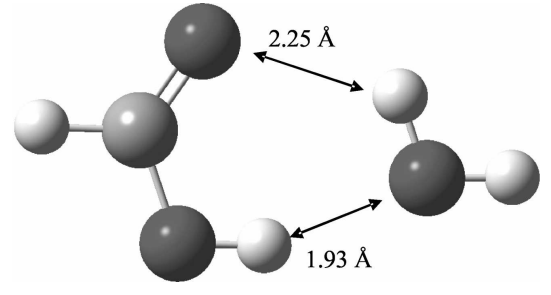

Fig. 3. The most stable associate of formic acid and water.

water and acid act as proton donor and proton acceptor. The free $\mathrm{OH}$ bond of water is at 120 degree angle with the plane of hydrogen bond. Such structure of this complex allows forming additional hydrogen bond with other molecules, producing hydrogen bond networks in highly concentrated samples.

\subsection{Acetic acid and water complexes}

Hydrogen bonding in acetic acid is also studied extensively $[2,16]$. It is agreed that in the gas phase acetic acid coexists as the mixture of monomers and cyclic dimers. In the solid state acetic acid forms long hydrogen bonded chains. The structure of hydrogen bonded selfassociates in the liquid phase is still an object of discussion. It is believed that in liquid phase both cyclic dimers and long hydrogen chains might coexist. Recently existence of open (chain) dimer was shown from matrix isolation by Sander et al. [17] and in supersonic jet expansion experiments by Suhm et al. [18].

The infrared absorption spectra of acetic acid are very similar to the spectra of formic acid. Therefore following the same analysis one can conclude that $\mathrm{C}=\mathrm{O}$ stretch region is the most suitable for the analysis of the formation of hydrogen bonded complexes. Infrared spectra, in this region, of water-acetic acid mixture isolated in argon matrix are presented in Fig. 4. In order to assign spectral bands theoretical calculations were performed at B3LYP level of theory using $6-311++\mathrm{G}(3 \mathrm{df}, 3 \mathrm{pd})$ basis function set [9]. Calculated wavenumbers of possible associates are summarized in Table 2. Similar structures of acetic acid selfassociates as in the case of formic acid are possible. The spectral band of the highest wavenumber $\left(1778.9 \mathrm{~cm}^{-1}\right)$ is assigned to the $\mathrm{C}=\mathrm{O}$ stretch vibrations of the monomer. This band is observable even when a very low concentration of pure acetic acid is present in the matrix. The observed value is very close to the calculated one (Table 2). Based on theoretical calculations spectral band at $1720.2 \mathrm{~cm}^{-1}$ is assigned to the cyclic dimer of acetic acid. Those assignments well agree with the data from publications where pure acetic acid is studied [17].

Spectral bands at 1764.9 and $1735.8 \mathrm{~cm}^{-1}$ are assigned to the open dimer. This assignment is based on the experiments performed at low concentration of pure acetic acid isolated in argon matrices. The remaining strong band in this region at $1729.8 \mathrm{~cm}^{-1}$ was assigned to the water-acetic acid complex. The calculated wavenumber value for the complex's $\mathrm{C}=\mathrm{O}$ vibration is in very good agreement with the one observed experimentally. This assignment is confirmed by matrix annealing experiments and experiments where the water concentration in the matrix is varied. When sample is prepared only from pure acetic acid the spectral band at $1729.8 \mathrm{~cm}^{-1}$ completely vanishes, and in experiments with a high concentration of water this band is much 


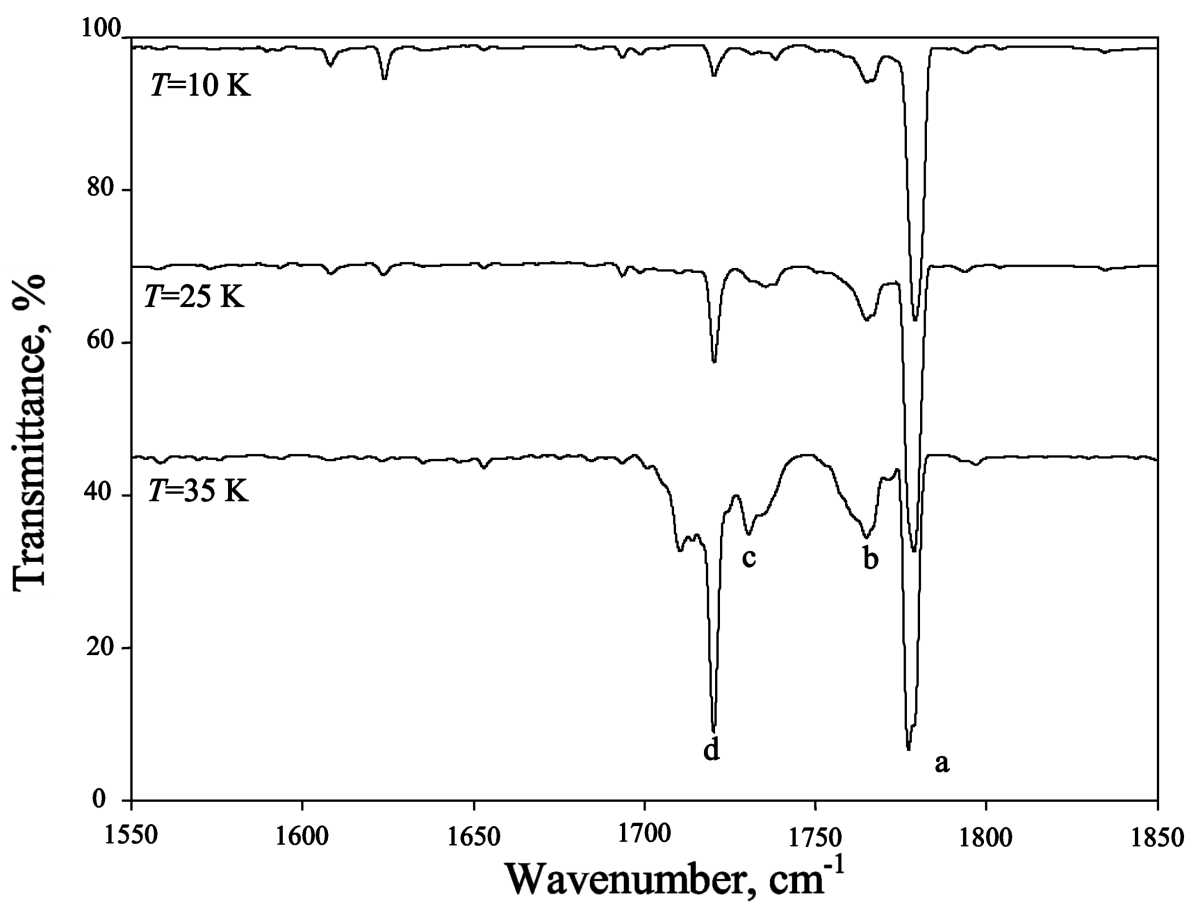

Fig. 4. IR absorption spectra of water-acetic acid mixture isolated in argon matrix at different temperatures. Water:acid:argon $=1: 2: 2000$ : (a) acid monomer, (b) acid open dimer, (c) water-acid complex, (d) acid cyclic dimer.

Table 2. Calculated energies and $\nu(\mathrm{C}=\mathrm{O})$ frequencies of acetic acid monomers, dimers, and acetic acid-water complexes.

\begin{tabular}{lccc}
\hline Structure & $\Delta H, \mathrm{~kJ} / \mathrm{mol}$ & $\nu(\mathrm{C}=\mathrm{O}), \mathrm{cm}^{-1}$ & Absorbance intensity, a. u. \\
\hline Monomer & - & 1782.5 & 293.2 \\
\cline { 2 - 4 } Dimer cyclic & -53.6 & 1669.9 & 0.0 \\
& & 1720.3 & 816.6 \\
\cline { 2 - 4 } Open dimer & -30.9 & 1767.7 & 645.8 \\
\cline { 2 - 4 } Acetic acid water 1:1 complex & -31.4 & 1741.3 & 106.8 \\
\cline { 2 - 4 } Acetic acid water 1:2 complex & -67.9 & 1732.0 & 279.2 \\
\hline
\end{tabular}

stronger than acetic acid dimer bands. Matrix annealing experiments (Fig. 4) allow one to observe the dynamics of complex formation in the matrix. When matrix is prepared using very high matrix to sample ratio (e. g. 1:4000) and deposited at the lowest possible temperature (8-9 K) only absorption due to monomeric species is observed. When the matrix is warmed, the local translational movement of molecules is enabled and the complex formation can occur. At not too high temperature only small 1:1 complexes can be formed, but at temperatures close to the ones when matrix starts to evaporate ( $40 \mathrm{~K}$ for argon) even complexes of 3 or 4 molecules can be formed. Spectral band $\left(1710 \mathrm{~cm}^{-1}\right)$ seen at $35 \mathrm{~K}$ (Fig. 4) is associated with formation of a complex with two water and one acetic acid molecule.

The most stable 1:1 complex between water and acetic acid (Fig. 5) has the similar cyclic structure as

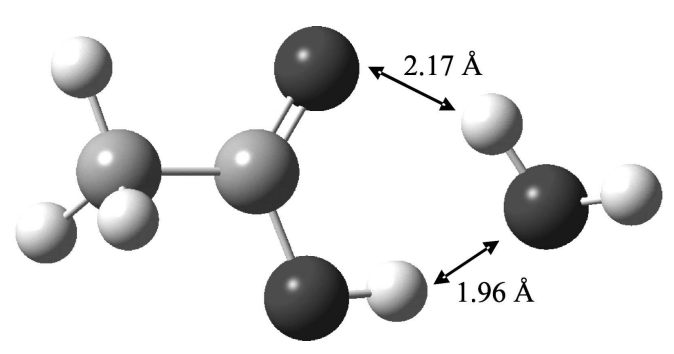

Fig. 5. The most stable associate of acetic acid and water.

water-formic acid complex. The calculated hydrogen bonding is weaker in the acetic acid case and the hydrogen bond length is bigger. It seems that additional carbon atom in the carboxylic acid is weakening its ability to form hydrogen bond with water. 


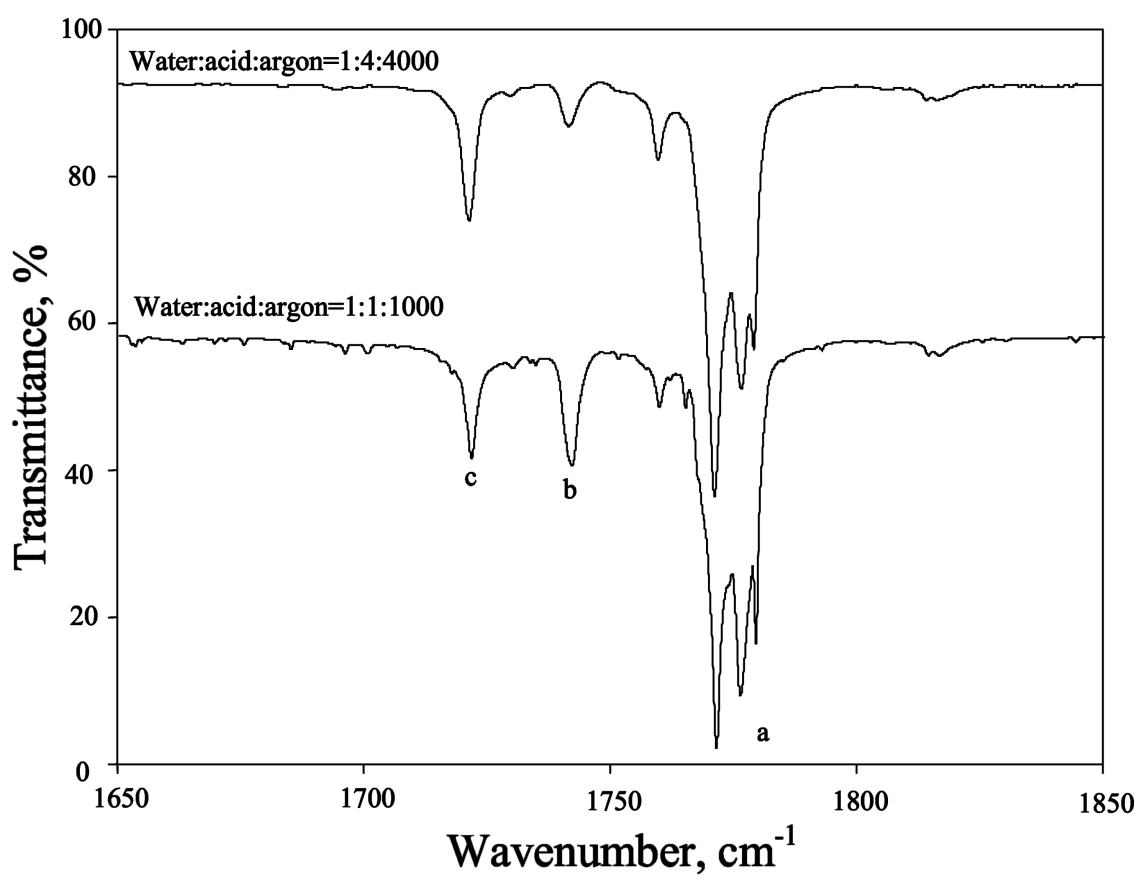

Fig. 6. IR spectra of water-propionic acid mixtures isolated in argon matrices (1:2:2000): (a) acid monomer, (b) water-acid complex, (c) cyclic acid dimer.

\subsection{Propionic acid and water complexes}

Propionic acid is studied much less than lighter carboxylic acids [17]. It is known that in the gas phase the propionic acid, likewise formic and acetic acids, exists as a mixture of monomers and cyclic dimers. In the condensed phase propionic acid also forms cyclic dimers. Possibility of the existence of open dimers in the solid matrices is not clear yet. Studies of propionic acid complexes are more complicated due to conformational diversity [19]. Radical chain of the propionic acid can be attached in several ways to the carboxylic group [19]. Existence of several different conformers complicates infrared spectra, because additional bands associated with each conformer can be observed. The same as in lighter acids $\mathrm{C}=\mathrm{O}$ stretch vibrations are most sensitive to the formation of the hydrogen bond complexes, therefore this spectral region has been chosen for the detailed examination.

Infrared spectra of water and propionic acid mixtures isolated in argon matrices are presented in Fig. 6. The highest wavenumber spectral band $\left(1776.6 \mathrm{~cm}^{-1}\right)$ is assigned to the $\mathrm{C}=\mathrm{O}$ stretch vibration of the propionic acid monomer. There is a slight problem with monomer band assignment due to the fact that close to the monomer band two additional spectral bands are observed. There are two possible explanations for the appearance of these lines: different conformations of propionic acid and matrix splitting effect. It is unlikely that two or more different conformers are trapped in

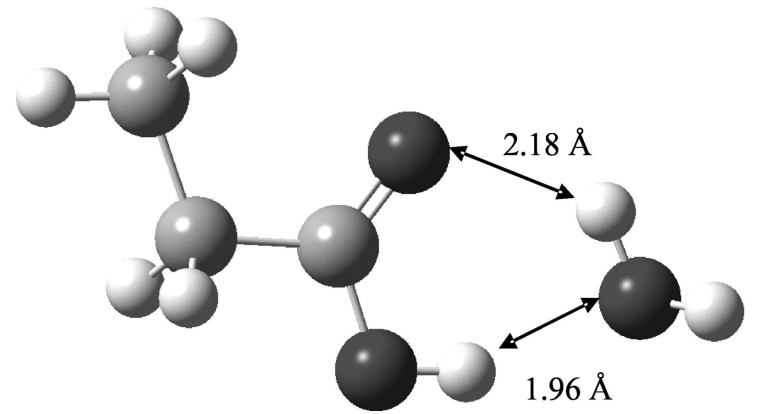

Fig. 7. The most stable associate of propionic acid and water.

the matrix. The energy difference between two closest conformers $(4.8 \mathrm{~kJ} / \mathrm{mol})$ is too high for the second conformer to be observable at low temperatures. This assumption is confirmed by the recent work of Macoas et al. [19] in the conformational study of propionic acid. Therefore appearance of two additional spectral bands is attributed to the environmental effect of the matrix. It is possible that for such large molecule as propionic acid several trapping sites in the matrix might exist. This results in slightly different matrix induced perturbation to the vibrations of the propionic acid. Assignment of monomeric band is in good agreement with calculations and the literature data $[17,19]$. Assignment of the remaining bands is based on theoretical calculations. Vibrational spectra of possible complexes were calculated using B3LYP method with $6-311++\mathrm{G}(3 \mathrm{df}, 3 \mathrm{pd})$ basis function set [9] (Table 3). Spectral band at $1721.4 \mathrm{~cm}^{-1}$ is assigned to the $\mathrm{C}=\mathrm{O}$ stretch vibrations 
Table 3. Calculated energies and $\nu(\mathrm{C}=\mathrm{O})$ frequencies of propionic acid monomers, dimers, and propionic acid-water complexes.

\begin{tabular}{lccc}
\hline Structure & $\Delta H, \mathrm{~kJ} / \mathrm{mol}$ & $\nu(\mathrm{C}=\mathrm{O}), \mathrm{cm}^{-1}$ & Absorbance intensity, a. u. \\
\hline Monomer & - & 1783.1 & 296.2 \\
Cyclic dimer & 53.5 & 1723.9 & 789.6 \\
Propionic acid-water 1:1 complex & 30.0 & 1740.5 & 242.8 \\
Propionic acid-water 1:2 complex & 67.3 & 1713.8 & 315.5 \\
\hline
\end{tabular}

of the propionic acid cyclic dimer. Absorption band related to water-propionic acid complex is observed at $1741.7 \mathrm{~cm}^{-1}$. This value is very close to the calculated one. Assignment of the complex band is also confirmed by the experiments when concentration of water is varied in the matrix sample (Fig. 6). Spectral band at $1741.7 \mathrm{~cm}^{-1}$ vanishes when water concentration is low, and becomes more intense than cyclic dimer band when water concentration is high. The origin of spectral band at $1759.4 \mathrm{~cm}^{-1}$ is not completely clear. Tentatively it can be assigned to the open dimer of propionic acid. Studying the samples with equal amounts of water and acid leads to conclusion that water-acid complex is somewhat more preferred to cyclic acid dimer. The reason of such complex formation might be the small size of water molecule. The small water molecule in the matrix mixture more easily approaches the propionic acid than another propionic acid molecule.

The most stable structure of propionic acid is presented in Fig. 7. The same as in lighter acids case the complex possesses cyclic structure. The strength of the complex is slightly weaker than in acetic acid case. The length of the hydrogen bonds is also increased. The lower hydrogen bond strength is also confirmed from the smaller red shift of the complex spectral band.

\subsection{Butyric acid and water complexes}

Even less experimental studies exist for the butyric acid. It is known that butyric acid forms cyclic dimers in the gas, liquid, and solid states in the same manner as propionic acid [2]. Butyric acid exhibits even richer conformational diversity, compared with propionic acid. Nevertheless, based on the considerations presented above the existence of different conformers in the low temperature matrices should be excluded, and multiple number of close lying lines at 1760$1780 \mathrm{~cm}^{-1}$ (Fig. 8) assigned to the monomer vibrations should be attributed to the matrix effect (matrix splitting). Increasing number of monomer lines could be explained by the fact that bigger molecule does not fit in a single substitutional site of matrix crystal and occupies two or even more sites. This results in greater number of slightly energetically different states.

The lowest $\mathrm{C}=\mathrm{O}$ region band at $1717.9 \mathrm{~cm}^{-1}$ (Fig. 8) is assigned to the cyclic dimer. This assignment is in very good agreement with theoretical data calculated

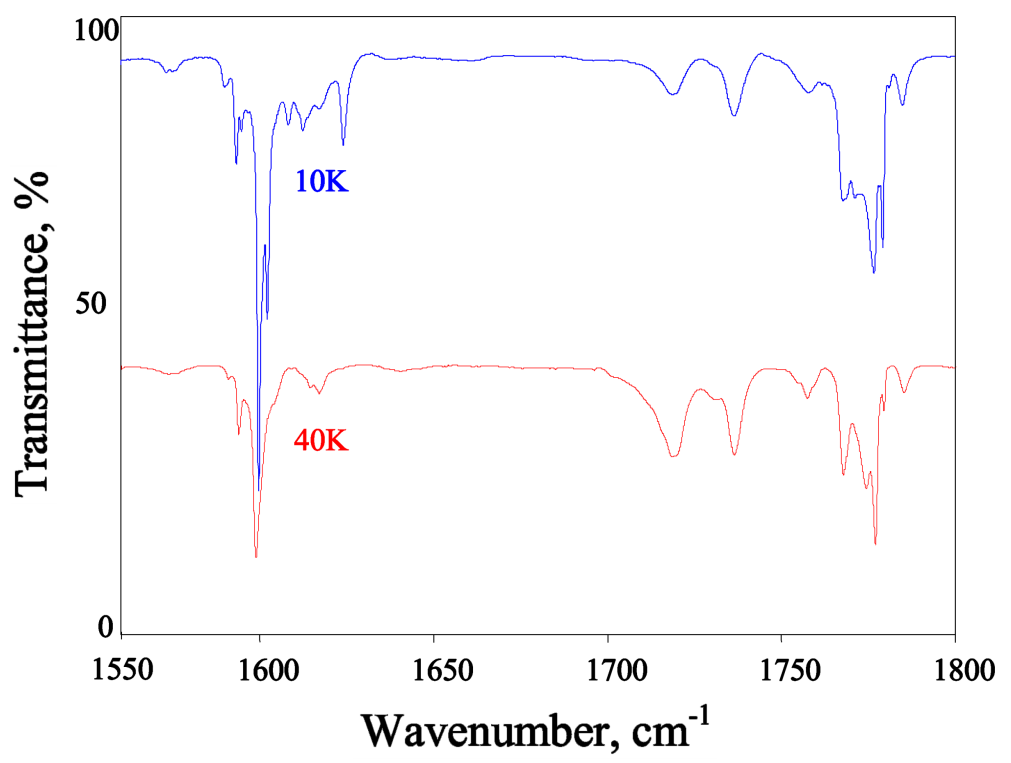

Fig. 8. IR spectra of water-butyric acid mixtures isolated in argon matrices (1:2:2000): (a) acid monomer, (b) water-acid complex, (c) cyclic acid dimer. 
Table 4. Calculated energies and $\nu(\mathrm{C}=\mathrm{O})$ frequencies of butyric acid monomers, dimers, and butyric acid-water 1:1 complex.

\begin{tabular}{lccc}
\hline Structure & $\Delta H, \mathrm{~kJ} / \mathrm{mol}$ & $\nu(\mathrm{C}=\mathrm{O}), \mathrm{cm}^{-1}$ & Absorbance intensity, a. u. \\
\hline Monomer & - & 1784.2 & 296.2 \\
Cyclic dimer & 53.6 & 1722.6 & 790.1 \\
Butyric acid-water 1:1 complex & 30.9 & 1739.4 & 253.8 \\
\hline
\end{tabular}

Table 5. Binding energies of various complexes and alternating behaviour of their band red shift.

\begin{tabular}{ccccc}
\hline Complex & $\Delta H, \mathrm{~kJ} / \mathrm{mol}$ & $\nu_{\mathrm{t}}(\mathrm{C}=\mathrm{O}), \mathrm{cm}^{-1}$ & $\nu_{\mathrm{e}}(\mathrm{C}=\mathrm{O}), \mathrm{cm}^{-1}$ & $\Delta \nu_{\mathrm{e}}(\mathrm{C}=\mathrm{O}), \mathrm{cm}^{-1}$ \\
\hline $\mathrm{HCOOH}_{\ldots} . \mathrm{H}_{2} \mathrm{O}$ & 32.0 & 1738.3 & 1736.7 & 31.0 \\
$\mathrm{H}_{3} \mathrm{C}_{2} \mathrm{OOH} \ldots \mathrm{H}_{2} \mathrm{O}$ & 31.4 & 1732.6 & 1730.7 & 49.5 \\
$\mathrm{H}_{5} \mathrm{C}_{3} \mathrm{OOH} \ldots \mathrm{H}_{2} \mathrm{O}$ & 30.0 & 1740.5 & 1741.9 & 34.4 \\
$\mathrm{H}_{7} \mathrm{C}_{4} \mathrm{OOH} \ldots \mathrm{H}_{2} \mathrm{O}$ & 30.9 & 1739.4 & 1736.6 & 39.6 \\
\hline
\end{tabular}

$\nu_{\mathrm{t}}$ calculated wavenumber, $\nu_{\mathrm{e}}$ experimentally observed value, $\Delta \nu_{\mathrm{e}}=\nu_{\mathrm{e}}($ monomer $)-\nu_{\mathrm{e}}($ complex $)$.

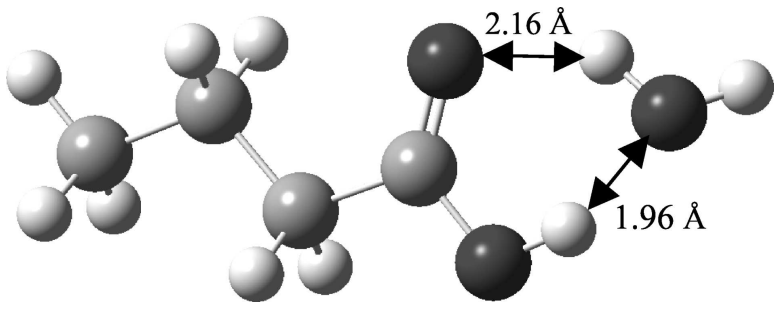

Fig. 9. The most stable associate of butyric acid and water.

using B3LYP method with 6-311++G(3df,3pd) basis function set [9] (Table 4). Spectral band at $1736.5 \mathrm{~cm}^{-1}$ is assigned to the butyric acid-water complex on the basis of theoretical calculations and experiments where water concentration in the sample is varied.

The most stable structure of water-butyric acid is also cyclic (Fig. 9). The strength of the complex is higher than in propionic acid's case but lower than the acetic acid's one (Table 5). This behaviour is also reproduced in the red shift of the complex band from the monomer absorption.

\subsection{Far infrared part of absorption spectra of the complexes}

In order to confirm the cyclic nature of carboxylic acid-water complexes the spectroscopic experiments in far infrared region were performed. Absorption in this spectral region is associated with vibrations of intermolecular bonds; thus direct information on the structure of molecular complexes could be obtained. Such kind of experiments are much more complicated, therefore only experimental studies on water-propionic acid were performed. The spectra of water, propionic acid, and water-propionic acid mixture isolated in $\mathrm{Ne}$ matrix is presented in Fig. 10. Far infrared spectrum of water is well assigned $[8,20]$, therefore it is possible to assign spectral bands to the water-propionic acid complex. Spectral bands at 281, 433, and $479 \mathrm{~cm}^{-1}$ are associated with water-propionic acid absorption. This assignment is in very good agreement with theoretical calculations when cyclic configuration is assumed. Calculated frequencies and intensities of the single bonded linear structures do not resemble the experimentally observed far infrared region data.

\subsection{Influence of carboxylic acid radical to the hydrogen bond strength}

Calculated binding energies of carboxylic acid and water complexes shows interesting behaviour with the increase of the $\mathrm{C}-\mathrm{C}$ radical chain (Table 5). The binding energy is decreasing with increase of the radical chain. But this decrease is not monotonous, it is alternating for even and odd numbers of carbon atoms in the chain. This calculated phenomenon is also observed experimentally. In the carboxylic acids, the red shift of the complex $\mathrm{C}=\mathrm{O}$ vibration from the corresponding monomer band is an indicator of the bond strength. The stronger complex binding energy results larger red shift. Alternating behaviour of complex band red shift (Table 5) confirms the idea of alternating binding energy. The alternating behaviour of the binding energy might be tentatively explained by the small influence to the hydrogen bond of hydrogen atoms from the nearest $\mathrm{CH}_{2}$ or $\mathrm{CH}_{3}$ groups.

\section{Conclusions}

Infrared spectra of water-propionic acid and waterbutyric acid complexes were observed and assigned for 


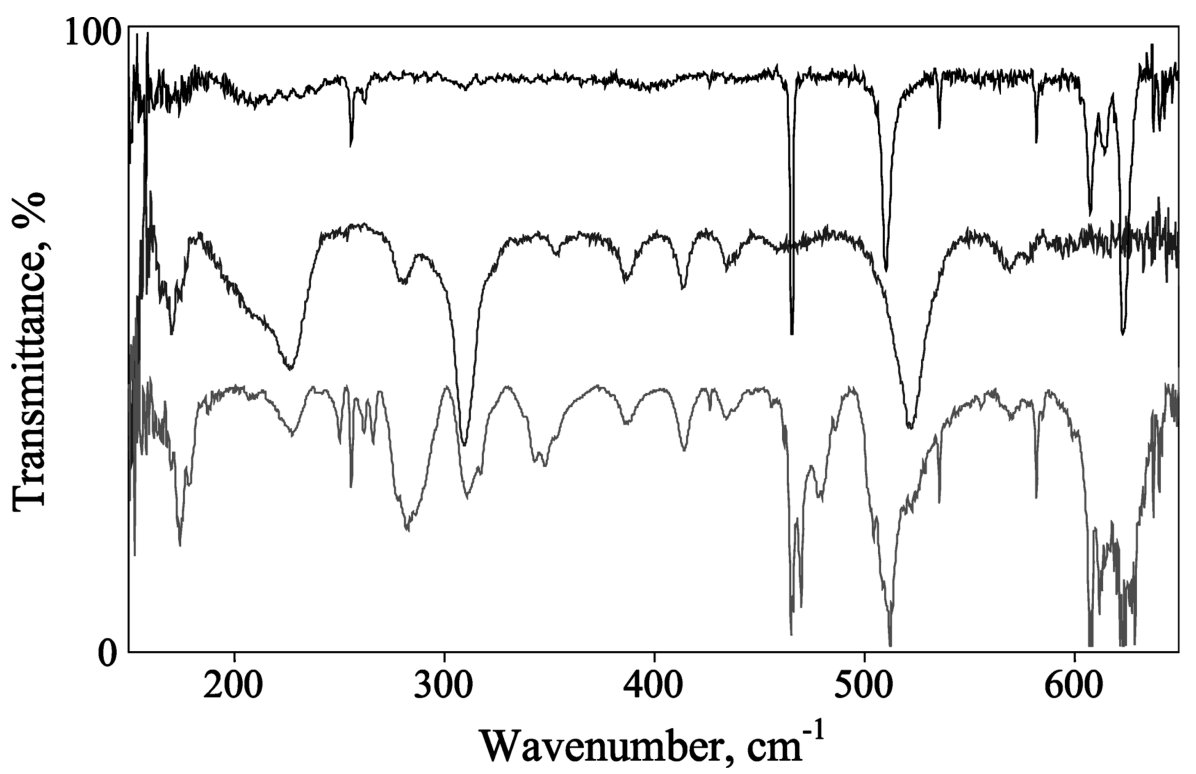

Fig. 10. Far infrared spectral region of propionic acid (top), water (middle), and acid-water mixture (bottom) isolated in Ne matrices.

the first time. Spectral region of $\mathrm{C}=\mathrm{O}$ stretch vibrations is the most suitable for the studies of hydrogen bond complexes in carboxylic acids. Based on the results of theoretical calculations and FTIR matrix isolation experiments it was elucidated that water and monocarboxylic acid 1:1 complex exhibits cyclic configuration. The remaining free $\mathrm{O}-\mathrm{H}$ bond of water forms $c a 120$ degree angle with the plane of hydrogen bond cycle. From the analysis of theoretical data and shifts of experimentally observed spectral bands it was calculated that the hydrogen bond strength in the water-carboxylic acid complex alternates for even and odd number of carbon atoms in the acid radical chain and decreases with the increase of carboxylic acid radical chain length.

\section{Acknowledgements}

Matrix isolation experiments at Vilnius University were partly financed by Lithuanian State Science and Studies Foundation through the grant V-46/2008. Experiments in the far IR were performed in the Lund National Synchrotron Radiation laboratory MAX-lab and supported by the European Community - Research Infrastructure Action under the FP6 "Structuring the European Research Area" Programme (through the Integrated Infrastructure Initiative "Integrating Activity on Synchrotron and Free Electron Laser Science"). Generous help from MAX-lab staff in performing experiments is gratefully acknowledged.

\section{References}

[1] P. Ball, Water - an enduring mystery, Nature 450, 291292 (2008).

[2] Y. Marechal, IR spectra of carboxylic acids in the gas phase: A quantitative reinvestigation, J. Chem. Phys. 87, 6344-6353 (1987).

[3] F. Genin, F. Quiles, and A. Burneau, Infrared and Raman spectroscopic study of carboxylic acids in heavy water, Phys. Chem. Chem. Phys. 3, 932-942 (2001).

[4] V. Sablinskas and J. Ceponkus, Self-association of formic acid. Theoretical and matrix isolation infrared absorption study, Environ. Chem. Phys. 25, 36-42 (2003).

[5] V. Balevičius, J. Čeponkus, V. Šablinskas, and H. Fuess, Anomalous structural changes in acetic acid / water solutions, Lithuanian J. Phys. 43, 183-187 (2003).

[6] D. Priem, T.-K. Ha, and A. Bauder, Rotational spectra and structures of three hydrogen-bonded complexes between formic acid and water, J. Chem. Phys. 113, 169175 (2000).

[7] L. George and W. Sander, Matrix isolation infrared and $a b$ initio study of the hydrogen bonding between formic acid and water, Spectrochim. Acta, Part A 60, 32253232 (2004).

[8] J. Čeponkus and B. Nelander, Water dimer in solid neon. Far-infrared study, J. Phys. Chem. A 108, 64996502 (2004).

[9] Gaussian 98, Revision A.3, M.J. Frisch, G.W. Trucks, H.B. Schlegel, G.E. Scuseria, M.A. Robb, J.R. Cheeseman, V.G. Zakrzewski, J.A. Montgomery, Jr., R.E. Stratmann, J.C. Burant, S. Dapprich, J.M. Millam, A.D. Daniels, K.N. Kudin, M.C. Strain, O. Farkas, J. Tomasi, V. Barone, M. Cossi, R. Cammi, B. Mennucci, C. Pomelli, C. Adamo, S. Clifford, J. Ochterski, 
G.A. Petersson, P.Y. Ayala, Q. Cui, K. Morokuma, D.K. Malick, A.D. Rabuck, K. Raghavachari, J.B. Foresman, J. Cioslowski, J.V. Ortiz, B.B. Stefanov, G. Liu, A. Liashenko, P. Piskorz, I. Komaromi, R. Gomperts, R.L. Martin, D.J. Fox, T. Keith, M.A. AlLaham, C.Y. Peng, A. Nanayakkara, C. Gonzalez, M. Challacombe, P.M.W. Gill, B. Johnson, W. Chen, M.W. Wong, J.L. Andres, C. Gonzalez, M. HeadGordon, E.S. Replogle, and J.A. Pople, Gaussian, Inc., Pittsburgh, PA (1998).

[10] B.S. Jursic, Can hybrid DFT methods correctly compute the potential energy surface formic acid dimerization and proton transfer in the formic acid dimer? A comparison of hybrid DFT computed values with experimental and G1, G2, and G2MP2 generated data, J. Mol. Struct. 417, 89-94 (1997).

[11] A.P. Scott and L. Radom, Harmonic vibrational frequencies: An evaluation of Hartree-Fock, MøllerPlesset, quadratic configuration interaction, density functional theory, and semiempirical scale factors, J. Phys. Chem. 100, 16502-16513 (1996).

[12] G.E. Tomlinson, B. Curnutte, and C.E. Hathaway, Temperature dependence of the Raman and infrared spectrum of liquid formic acid, J. Mol. Spectrosc. 36, 26-33 (1970).

[13] M. Gantenberg, M. Halupka, and W. Sander, Dimerization of formic acid - an example of "noncovalent" re- action mechanism, Eur. J. Chem. 6, 1865-1869 (2000).

[14] P.O. Åstrand, G. Karlström, A. Engdahl, and B. Nelander, Novel model for calculating the intermolecular part of the infrared spectrum for molecular complexes, J. Chem. Phys. 102, 3534-3554 (1995).

[15] A.S. Engdahl, Intermolecular interactions in hydrogen bonded 1:1 complexes. A matrix isolation study, doctoral dissertation (Lund, 1997).

[16] Y. Grenie, J.C. Cornut, and J.C. Lassegues, Infrared spectra of matrix isolated acetic acid dimers, J. Chem. Phys. 55, 5844-5846 (1971).

[17] W. Sander and M. Gantenberg, Aggregation of acetic and propionic acid in argon matrices - A matrix isolation and computational study, Spectrochim. Acta, Part A 62, 902-909 (2005).

[18] C. Emmeluth and M.A. Suhm, A chemical approach towards the spectroscopy of carboxylic acid dimer isomerism, Phys. Chem. Chem. Phys. 5, 3094-3099, (2003).

[19] E.M.S. Macuoas, L. Khriachtchev, M. Pettersson, R. Fausto, and M. Rasanen, Internal rotation in propionic acid: Near-infrared-induced isomerization in solid argon, J. Phys. Chem. A 109, 3617-3625 (2005).

[20] J. Čeponkus, G. Karlström, and B. Nelander, Intermolecular vibrations of the water trimer, a matrix isolation study, J. Phys. Chem. A 109, 7859-7864 (2005).

\title{
VANDENS IR NEDIDELIŲ MONOKARBOKSIRŪGŠČIŲ ASOCIATŲ TYRIMAS MATRICINĖS IZOLIACIJOS FTIR SPEKTROMETRIJOS METODU
}

\author{
J. Čeponkus, D. Leščiūtè, D. Čepulinskaitè, M. Pučetaitè, V. Šablinskas \\ Vilniaus universitetas, Vilnius, Lietuva
}

\section{Santrauka}

Vanduo daro ịtaką daugeliui cheminių, fizikinių ir biologinių procesų, vykstančiu gamtoje. Vandens molekulès dèl savo dydžio gali būti priskirtos nesudètingų molekulių klasei. Tačiau dèl savybės sudaryti su aplinkinėmis molekulėmis stiprius vandenilinius ryšius vandens molekulès dažniausiai yra didesnių molekulinių darinių sudètinè dalis.

Vandens ir karboksirūgščių asociatų tyrimai yra svarbūs keletu aspektų. Nedidelès karboksirūgštys yra plačiai paplitusios gamtoje, todèl svarbu žinoti, kaip vanduo veikia šių medžiagų savybes. Vandens ir nedidelių organinių molekulių asociatai gali būti geras modelis, siekiant suprasti vandenilinio ryšio ypatybes sudètingose sistemose.

Infraraudonoji (IR) spektrometrija yra vienas geriausiu metodu ivvairioms molekulinèms sistemoms tirti. Analizuojant IR sugerties spektrus galima gauti tiesioginę informaciją apie branduolių virpesius molekulèje. Ši informacija leidžia nustatyti tiriamos molekulès struktūrą bei įvairius dinaminius parametrus. Matricinès izoliacijos metodas praplečia IR spektroskopijos galimybes tyrinèti izoliuotas molekules ir molekulinius kompleksus.

Spektrinės juostos buvo priskiriamos vandens ir karboksirūgšties asociatui, naudojantis eksperimentų, atliktų keičiant bandinių ir matricos santykus, bei teorinių kvantinès chemijos skaičiavimų rezultatais.

Tyrimų metu užregistruotos vandens ir karboksirūgščių asociatų spektrinés juostos, pirmą kartą nustatyti acto rūgšties ir vandens, propiono rūgšties ir vandens bei sviesto rūgšties ir vandens kompleksų energiniai parametrai ir sandara. Nustatyta, kad vandenilinio ryšio energija mažèja, didèjant karboksirūgšties radikalui. 